\title{
RELATIONSHIP BETWEEN POLITICAL PARTIES AND CHURCHES AS ACTORS OF PUBLIC POLICY IN SLOVAKIA
}

\author{
PhDr. Dalibor MIKUŠ, PhD.
}

\begin{abstract}
The political changes of 1989 affected almost all areas of social life in a decisive manner. In the conditions of religiously based Slovakia, religious freedom is objectively considered one of the key achievements of the velvet revolution. In the process of democratization, the subordination of churches and religious societies to the state was removed, thus creating a new quality of relations. So far, however, there has been no separation of state and churches in terms of their funding, which is the subject of public discussion in the long run. Political parties are key actors in the whole process, as they have the political power to bring about concrete changes. In this article, we focus on the relationship between political parties and churches from several perspectives. On the one hand, we evaluate the role of specific political entities in the process of democratization of society, on the other hand, we analyse the current views of parliamentary political parties on the issue of church financing and general separation. Based on the evaluation of the issue in the countries of the Visegrad Group, we identify various models as example for Slovakia. At the same time, we rely on the conducted interviews with representatives of selected political parties, whom we addressed to maximize the outputs of this paper.
\end{abstract}

\section{Keywords}

church, political parties, political actors, reform, funding of churches

\section{Introduction}

We rank political parties and churches among the important actors of public policy in Slovakia. A common milestone of development is the year 1989, when the democratization of society was reflected in the qualitative increase of their scope. While the removal of the Communist Party's leading role in society in the case of political parties was reflected in the formation of a pluralistic system in terms of democratic competition, the churches emerged from the rule of the state in terms of direct decision-making. At the same time, the way of financing has been almost maintained reflecting the strengthening of the links between the two types of actors. In this article, we focus on the development of churches in Slovakia after 1989 in terms of the scope of political parties, as well as current evaluations of views on the financial separation of the state and the church. By analyzing the models 
in the countries of the Visegrad Group, we present alternative proposals. In addition, we devote to parliamentary political parties, which have the power to submit specific legislative norms. We rely on the conducted interviews with representatives of political parties explaining the attitudes of the entities to the issue of the position of churches in society.

\section{The position of churches in the context of democratization of society}

Political changes in 1989 significantly affected individual areas of society. The Communist Party's monopoly on state control was ended by a combination of geopolitical changes and the activation of civil society. On the basis of this, Czechoslovakia managed to break out of the Eastern bloc in cooperation with movements in the surrounding countries, which were also dominated by the Communist Party. Representatives of the power of democratic forces at that time faced the challenging task of defining the setting of processes leading to the creation of a free society in the spirit of advanced democracies. The paramount task was to ensure democratic elections, which are a fundamental building block of the exercise of civil rights. However, democratization was related to a wide range of systemic changes implemented over a longer time horizon. The restoration of religious freedom also began to be linked to the question of the position of churches and religious societies in this entire process. The main attention was paid to the Roman Catholic Church, to which $60.4 \%$ of the population of Slovakia reported on the basis of the 1991 census."

During the communist era, the Roman Catholic Church was in a difficult position. The goal of state power was to subordinate this institution in order to pursue their goals without hindrance, because in practice the churches were essentially the only opposition after the elimination of democratic political parties. On this basis, the model of direct financing from state resources was enforced, which was to bring the church under the control of the central power. ${ }^{2}$ It was primarily control of the Roman Catholic Church for two reasons. In the first place, the Roman Catholic Church partly represented the heritage of the Slovak state, as Roman Catholic representatives were the leaders of the state. The connection with the people's regime during the war guaranteed the Roman Catholic Church a privileged position in the system of state organizations. In practice, almost a third of the members of the Slovak parliament were priests, and this ratio also applied to the positions of district administrators who were at the head of regional administrative units. The Roman Catholic Church was, in fact, part of the state administration as such. ${ }^{3}$

Any disagreeing opinion of church leaders after 1948 was considered by the communist power as a manifestation of the effort to restore the people's regime. On the other hand, the Communist Party considered the Vatican's influence to be a direct threat because the Holy See opposed the Communist dictatorships, which was reflected in the published encyclicals. In the period of socialism, the model of the supremacy of the state over the churches was enforced based on the adopted legislation. The centralized system

1 STATISTICAL OFFICE OF THE SLOVAK REPUBLIC.

2 PEŠEK, Ján: Štátnopolitické orgány dozoru nad cirkvami na Slovensku v rokoch 1948-1989, 518-519.

3 ŠABO, Martin: Systém vztáhov medzi štátom a cirkvami v Československu pred prijatím zákona č. 218/1949 Zb. o hospodárskom zabezpečení cirkví a náboženských spoločností, 194. 
of church administration by the State Council was ensured through Act no. 217/1949 Coll. At the practical level, this meant completely subordinating the activities of the church to this body located in the hierarchy of power at the level of ministries. Economic subordination was defined by Act no. 218/1949 Coll. According to its wording, the financing of the church passed entirely to the state, while the basic condition for the remuneration of the clergy was to take an oath to the republic. Due to Act no. 218/1949 Coll., the Roman Catholic Church has lost its status as a subject of public law, and at the same time the process of nationalization of property began without the prospect of any compensation. ${ }^{4}$

Although the legislation experienced several amendments until 1989, the basic character of the relationship between the Roman Catholic Church and the state and the leading position of the Communist Party was firmly defined by a hierarchical system of superiority and subordination. At the same time, it is also necessary to state that in the case of Czechoslovakia, it was a stricter church policy compared to the surrounding countries of the Eastern bloc. In Slovakia, this was particularly evident, as it was a more religious part of the common state with the Czechs. This was reflected in a louder expression of the demand for civil liberties, which was caused not only by the strong representation of Catholics in society, but also by the historical interconnectedness of the national movement with the ecclesiastical spheres. In this context, it is necessary to point out the Candle demonstration in Bratislava, which took place on March 25, 1988 on Good Friday. Citizens expressed their opposition to human rights violations in Czechoslovakia by silent candlelight protests, although the state committed to respecting civil rights in the framework of the International Covenant on Civil and Political Rights adopted at the CSCE conference in Helsinki. In practice, it was until then one of the largest public appearances against communist power, which ended in intervention by public security forces. At the same time, however, we can conclude that, despite the violent suppression of the demonstration, the regime has shown its weakness because it has not been able to solve the issue through dialogue and reform. ${ }^{5}$

After 1989, political elites faced the difficult task of optimizing their relations with the churches. Already at the beginning of 1990, Act no. 16/1990 Coll. on the abolition of state supervision over churches was approved. Based on it, state supervision over the church and the appointment of its clergy was abolished. The government thus stopped interfering in the internal affairs of the churches. The first free elections in 1990 became a decisive milestone when citizens confirmed the democratic direction of the state. Christian voters were mainly represented by the political entity KDH (Christian Democratic Movement), which finished in second place behind the VPN (Public Against Violence Movement). However, the formed governing coalition clearly set the goal, which is to ensure the free position of churches and to prepare legal preconditions for the beginning of the process of restoration of stolen property by the previous regime. During the preparation of the legislation, the representatives of $\mathrm{KDH}$ were the actors who ensured the achievement of the set goals. ${ }^{6}$ The new mechanism was based primarily on Act no. 308/1991 Coll.

4 MULíK, Peter: Metódy a formy proticirkevnej politiky $v$ komunistických štátoch strednej a juhovýchodnej Európy a ich zmeny $v$ rokoch 1945-1989, 249.

5 MARUŠIAK, Juraj: Sviečková manifestácia v kontexte vztáahov medzi "krestáanským” a „občianským” disentom v rokoch 1988-1989, 58.

6 MIKUŠ, Dalibor: Pohlady politických strán na verejnú správu, 34. 
on Freedom of Religion, the Status of Churches and Religious Societies, and Constitutional Act no. 460/1992 Coll. Last but not least, the new Constitution of the Slovak Republic ensuring the plurality of religion, the free existence of churches and religious societies also had its undeniable weight as well.

An important topic was also the restitution of church property, which had the task of returning confiscated church property in the years 1945 to 1989 . This was primarily addressed by Act no. 403/1990 Coll. On mitigating the effects of certain property wrongs, Act no. 229/1991 Coll. on the regulation of ownership relations to land and subsequently by Act no. 282/1993 Coll. on the alleviation of certain property wrongs caused to churches and religious societies. However, the adopted legislative changes did not address the complexity of the relationship between the state and the church in terms of the tendency to separate the church from the state completely. It is a paradox that although this demand sounded quite often in the last stage of the existence of the socialist establishment, after the social changes that have created space for it, the idea did not take hold. In the petition of Catholic clergy from 1987 entitled Initiatives of Catholics to solve the situation of believing citizens in the Czechoslovak Socialist Republic, the separation of the state from the church was clearly demanded in an effort to ensure its independent status. After 1989, space was created for the implementation of this step, but it still never took place. First of all, it was because of the absence of political will and agreement with the churches, but above all with the Roman Catholic Church. If we put these aspects in the context of actors in the form of political parties, we can see an interesting fact in the 1990s. Two political parties were interested in acting in the interests of the Roman Catholic Church - the mentioned KDH and HZDS (Movement for Democratic Slovakia), which was created by splitting from the original party VPN. It was the HZDS that was the dominant entity on the political scene from 1992 to 1998, and no deeper reform took place due to the reserved position of the Roman Catholic Church. The position of the Roman Catholic Church was founded on a historical basis and a strong representation of believers according to statistical indicators after 1989. According to Tízik, the Roman Catholic Church was perceived as a leading force in the ideological and moral rebirth of society and its recommendations were like engines of social change. ${ }^{7}$ Last but not least, its influence could have been a significant factor in voter decision-making in the electoral process. Aware of this fact, the HZDS implemented a policy of cooperation with the Roman Catholic Church, which was already reflected in the aforementioned restitutions. In 1997, party chairman Vladimír Mečiar publicly declared that the church had the right to actively intervene in public events. He argued that the church must have an influence on political decision-making in accordance with the principles of faith. ${ }^{8}$ Based on these statements, the Roman Catholic Church acted as a partner of state power, although according to the Constitution of the Slovak Republic, Slovakia is not bound by any ideology. The 1998 parliamentary elections marked a significant milestone because, according to several political analysts, it was a struggle for the country's character. The main topic of the elections was the figure of the Prime Minister, above mentioned V. Mečiar, who significantly polarized society. Citizens should have made it clear whether they agree with the policy of the incumbent Prime Minister, which places Slovakia in international isolation.

7 TIŽ̌lK, Miroslav: Náboženstvo vo verejnom živote na Slovensku, 128.

8 MIKUŠ, Dalibor: Pohlady politických strán na verejnú správu, 37. 
The Roman Catholic Church was also an important player on this issue, but it did not speak with one voice. According to Marušiak, most clergy tended to $\mathrm{KDH}$, but there was also the support of HZDS and V. Mečiar, but this was particularly the case of specific or individual cases. However, this relationship could lead to the politicization of the church with negative consequences in the form of the loss of believers. ${ }^{9}$ Eventually, the Roman Catholic Church became an important player in the process of removing Vladimír Mečiar from the leading positions, which was confirmed by the results of the parliamentary elections.

Under the cabinet of Mikuláš Dzurinda, also backed by members of the KDH, the Roman Catholic Church supported the conclusion of a bilateral treaty with the Vatican, which was reached in 2000 . The basic treaty between the Holy See and Slovakia regulated relations between the two entities under international law. The treaty was drafted in the form of a framework contract conditional on the adoption of four further implementing contracts. However, the treaty was legally unbalanced in nature, as obligations arose for only one party. It declared the strengthened position of the Roman Catholic Church in Slovakia, while specific points were already the subject of the implementation of the contracts. The first of them was contract no. 648/2002 on the spiritual service of Catholic believers in the armed forces and in the armed corps, which established the conditions for the performance of service also in the Police Force, the Railway Police or the Prison and Judicial Guard Corps. Subsequently, there was a contract no. 394/2004 Coll. on Catholic education and the declaration of equality for church schools, including the teaching of religion in public schools. Significant political tensions were caused by the contract on the right to conscientious objection, which was negotiated in 2005 and 2006. The Roman Catholic Church supported the adoption of the contract, whereas $\mathrm{KDH}$, as one of the governing parties, made the adoption of this conscientious objection conditional on its remaining in the governing coalition. In terms of content, the draft agreement allowed healthcare professionals to refuse to participate in abortions, artificial insemination, sterilization or experiments with human organs. In addition, workers would have the right to refuse work on Sundays, and teachers were free to decide whether or not to teach sex education. However, the other parties of the coalition, SDKÚ-DS (Slovak Democratic and Christian Union - Democratic Party) and the party representing the interests of the Hungarian national minority SMK (Hungarian Coalition Party) proposed to amend the points of this contract. However, the $\mathrm{KDH}$, as an extended arm of the Roman Catholic Church, was in principle in favour of accepting the original proposal only. The nonapproval of the contract resulted in the withdrawal of the party from the government coalition and the announcement of early elections in 2006, 3 months before the due date was set. ${ }^{10}$ Based on the analysis of the political scene, we can state that it was largely a political calculus in terms of value and efforts to maximize profits in the parliamentary elections after eight years of participation in the governing coalition. However, we clearly managed to identify the connection between the Roman Catholic Church and the political entity $\mathrm{KDH}$ in an effort to enforce a specific legal norm.

9 MARUŠIAK Juraj: Sviečková manifestácia v kontexte vztáhov medzi "krestáanským” a „občianským” disentom v rokoch 1988-1989, 63.

10 JUST, Petr: Nad Tatrou sa blýska - strany, vlády a koalice na Slovensku v letech 2006 až 2016, 114. 


\section{Evaluation of the current position of parliamentary political parties in relation to churches}

From the point of view of the relationship between the state and the churches, the primary problem at present seems to be the establishment of a new model of church financing, which is the subject of long-term discussions. As mentioned above, on the one hand, after the political changes in 1989, a model of internal self-government of churches and religious societies was created, but on the other hand, economic connections to the state were not removed and thus the discussed separation of the church from the state did not take place. Representatives of the state power amended only the original law no. 218/1949 Coll. on the economic security of churches and religious societies, negating the direct supervision of the state over individual church activities. At the same time, however, the paternalistic principle in the relationship between the state and the churches has been preserved. Amendment to Act no. 522/1992 Coll. declared the provision of a salary to the clergy, if so requested by a particular registered church. On this basis, the funds were paid out in accordance with the salary tables which were regulated by the Regulation of the Government of the Slovak Republic. This made the priests civil servants. In addition, the role of the state was to contribute to the maintenance of sacred monuments. In practice, a separate chapter of the state budget was created, while the allocated funds were subject to the administration of the Ministry of Culture of the Slovak Republic. Subsequently, the funds were distributed through the relevant church departments. The financing system thus to a large extent maintained the connection between the state and the churches in terms of the transfer of financial contributions from the state budget.

An important factor for the implementation of changes is the comparison with the models in other countries of the Visegrad Group. The Czech Republic as the part of the former Czechoslovakia had the same legislation as Slovakia in 1993. Churches were funded by the state despite the declining number of believers. According to statistics, the largest Roman Catholic Church recorded a decline in believers from 39.03\% in 1991 to $10.37 \%$ in 2011. However, any changes were limited by the absence of political will. The 2010 legislative election was the main impetus for making the reform. The new governing coalition formed by the Civic Democratic Party (ODS) along with the liberal-conservative TOP 09 and Public Affairs (VV) pushed for a new system of church funding to cut off state contributions. Based on the legislation adopted in 2012, a system of gradual reduction of contributions in the longer term was established. Since 2013, the applied model has reduced state contributions by $5 \%$ each year. Therefore, state funding of churches will end in 2030. On the other hand, the model is associated with the payment of damages through the return of property to the church. Political parties and churches have been able to find a compromise and adopt a rational solution. ${ }^{11}$

Poland is a specific case with the Roman Catholic Church as an important actor. According to 2015 demographics, $92.9 \%$ of Poland's population is part of this church. At the same time, it is necessary to emphasize the significant role of the Roman Catholic Church

11 PŘIBYL, Stanislav: Problémy spjaté s utvářením nového modelu financování cirkví v České republice, 126. 
in the process of the fall of the communist regime. Nevertheless, the separation of church and state took place in 2014. The same as in the case of Czech Republic, the parliamentary elections in 2011 were a decisive factor. The Civic Platform (PO) as a centre-right and liberal party headed by Donald Tusk managed to win and form the government in the years 20112015. Following the example of Western European countries such as Germany and Italy, it has pushed for the adoption of new legislation introducing a church tax. Every citizen has the right to support the church in the amount to $0.5 \%$ of the total income tax. ${ }^{12}$ The original church fund subsidized by the state was replaced by a system of individual decision-making of each citizen. Although the conservative political party the Law and Justice (PiS) has played a key role in Poland since 2015, the voluntary mechanism has been maintained.

The issue of financing churches in Hungary began to be addressed in the 1990s. Under the government headed by the Hungarian Socialist Party (MSZP), an assignment tax model was introduced. Citizens can give $1 \%$ of their income tax to one of the churches. However, the applied system has the character of combined financing because the state provides funds for churches as well. ${ }^{13}$ After Viktor Orbán gained power with FIDESZ, new legislation on churches was adopted in 2012. There were new conditions for the recognition of churches, such as the existence of 100 years or 20 years of activity in Hungary. The original 360 state-recognized churches were reduced to $32 .{ }^{14}$ By summarizing the individual cases of Visegrad Group, Slovakia remains the only country without addressing this issue.

Eyeing at developments over the last three decades, individual government groups have applied two unwritten rules. The change will primarily be accepted only on the basis of a broad consensus of political parties and individual churches, and at the same time the right of churches to contributions from the state budget will be respected. Political parties considered the opening of this Pandora's box a sensitive area, also given the high percentage of believers and historical tradition. However, changing social conditions exerted some pressure to change the setting, which was still based on legislation passed in 1949. It was not until almost seventy years later that political parties and church leaders finally agreed to push for reform. Specifically, it is Act no. 370/2019 Coll. on financial support for the activities of churches and religious societies, submitted by the Ministry of Culture of the Slovak Republic during the reign of Peter Pellegrini. If we look at the specific results of the vote of the National Council of the Slovak Republic on 16 October 2019, we identify a high degree of political agreement across the governing coalition and the opposition. Of the 141 votes in total, 115 deputies voted in favour of the Act, while in addition to government deputies for SMER-SD, SNS and MOST-HÍD, deputies from opposition entities from OLANO, SME RODINA and L'SNS also voted in favour of the proposal. Only members of the opposition SaS refused to express a practically positive opinion procedurally, where none of the 20 members of the parliamentary group voted in favour of the proposal. ${ }^{15}$ In this case, we can mention that it is a liberal entity that has long promoted the separation of the state from the church. According to its deputy Alojz Baránik, the proposed legislation

12 WADOWSKI, Dariusz: Religion and Religiosity in Contemporary Poland, 44.

13 SCHANDA, Balázs: Financovanie cirkví a náboženských spoločností v Madarsku, 84.

14 ŠABO, Martin: Moderné spôsoby priamej podpory štátu cirkvám a náboženským spoločnostiam vo svete, 102.

15 NATIONAL COUNCIL OF THE SLOVAK REPUBLIC: Details of Act no. 370/2019 Coll. on financial support for the activities of churches and religious societies. 
does not change the essence of the functioning of the system. If we look at the specific points of this law, it maintained primarily state contributions to the church. However, a specific key has been introduced according to which funds would be distributed. The church was still entitled to state contributions, but compared to the previous situation there was a change. In the past, the finance minister could stop funding at any time, although no minister has ever exercised this right. Under the new conditions, however, a clearly defined formula based on several variables began to be applied. An important indicator was the number of believers, which critics described as a support point for the largest Roman Catholic Church. The principle of solidarity and indexation was also automatically incorporated, taking into account inflation and wage growth in public administration. At the same time, the self-government of churches was also strengthened in relation to the use of funds, as churches were no longer limited by obligatory allocation. An example is the abolition of the salary tables of clergy, on the basis of which funds no longer had to be allocated exclusively to the salaries of clergy.

If we emphasized the element of a broad consensus of political parties and church leaders, in this case there was a great deal of agreement. We can demonstrate this not only in the results of the vote in Parliament itself, but also in the overall timeframe for the adoption of this change. We consider the establishment of an expert commission within the Ministry of Culture of the Slovak Republic in 2011 to be a prerequisite when the ministry was in the hands of the SaS political party. After the premature fall of the entire government of Iveta Radičová and the accession of Marek Mad'arič to the ministerial chair as the nominee of SMER-SD, he continued the work of his predecessor by establishing a church department under the leadership of Ján Jurán. As a result, the discussion with the churches was taken to a higher level and individual stakeholders were allowed to submit their comments. At this stage, the tax allocation model was rejected because it met with opposition from representatives of smaller churches with the argument of creating competition for non-profit organizations. In addition, the model of tax allocation was not supported by the representatives of political parties either, as this proposal was supported only by the SaS from the position of an opposition entity. The Ministry of Culture of the Slovak Republic decided on the preparation of a law that modified the applied system by including a specific mechanism. If we look at specific numbers, we can observe an increase in the income of the largest churches. ${ }^{16}$

16 MIKUŠ, Dalibor: Pohlady politických strán na verejnú správu, 67. 
Table 1 Financial contributions for churches and religious societies

\begin{tabular}{|l|c|c|c|}
\hline Churches & $\begin{array}{c}\text { Percentage } \\
\text { of church members }\end{array}$ & $\begin{array}{c}\text { State contribution } \\
\text { in 2019 }\end{array}$ & $\begin{array}{c}\text { State contribution } \\
\text { in 2020 }\end{array}$ \\
\hline $\begin{array}{l}\text { Roman Catholic } \\
\text { Church }\end{array}$ & $62,02 \%$ & 31191337 eur & 34538722 eur \\
\hline Evangelical Church & $5,86 \%$ & 4858489 eur & 5174749 eur \\
\hline $\begin{array}{l}\text { Greek Catholic } \\
\text { Church }\end{array}$ & $3,83 \%$ & 4900043 eur & 5106921 eur \\
\hline Reformed Church & $1,83 \%$ & 2653763 eur & 2752563 eur \\
\hline Orthodox Church & $0,91 \%$ & 2029714 eur & 2078849 eur \\
\hline
\end{tabular}

Source: Ministry of Culture of the Slovak Republic

Based on the data in the table, it is necessary to emphasize that the share of believers is founded on the last census in 2011. Looking at the political scene, we add that several political parties perceive the adoption of Act no. 370/2019 Coll. on financial support for the activities of churches and religious societies only as a first step towards a comprehensive change, not as a final state. Based on this, we focused on the evaluation of the opinions of individual parliamentary political parties, their classification according to the traditional division into coalition and opposition political parties.

\section{Coalition political parties}

Looking at the current governing coalition, we can identify diversity in terms of access to value issues. On the one hand, we have more conservative entities such as OLANO and ZA L'UDÍ, on the other hand, there is liberal SaS as well. However, the very definition of the political orientation of the dominant political entity OLANO, which won more than $25 \%$ of the votes in the 2020 parliamentary elections, is problematic. In essence, it is not a classical political party as it does not have precisely defined internal structures. In terms of ideological focus, it is rather a broad-spectrum grouping with a strong wing of conservatives. If we look at the OL'ANO election program, it does not contain the problems of changes in the financing of churches. We also observe this element in the case of the government program. The main reason is the inconsistent approach of political parties to value issues, which could provoke conflicts. According to the Minister of Culture Natália Milanová, the current state of funding for churches is not ideal, but on the other hand there is no political will to make a change. She does not consider it right to put this issue at the forefront, as this could lead to contradictions in the governing coalition. Value issues were excluded from the coalition agreement and left to individual decisions of deputies.

This position is understandable, as the coalition includes the SaS party, which won $6.22 \%$ of the vote in the parliamentary elections. It has long established itself as a liberal entity that defends the individual rights of the individual and advocates for equality. As early as 2010, 
during its first participation in the governing coalition, the party proposed the introduction of an assignment tax modelled on Germany, in which every citizen would decide whether to provide funding to a particular church or not. SaS justified this with arguments that in the set system there is no complete independence of churches tied to state contributions. However, as we have said, this proposal has not received wider political support. At the same time, the $\mathrm{SaS}$ is a critic of the adopted Vatican Treaty, which it considers to be a unique case of a legal act in European conditions governing a wide range of competencies. SaS even initiated proceedings before the Constitutional Court of the Slovak Republic for violation of the equality of two international entities. While Slovakia has only obligations under this treaty, the Vatican has only rights. The contract also does not contain a termination section, allowing only changes by agreement of both parties. The long-term development of the SaS party clearly shows the agenda of the department of the state and the church. However, due to differing views on this issue, the SaS did not insist on the inclusion of this issue in the government's program statement. However, the approach of this party can be considered the most radical approach in terms of implementing concrete changes towards the church among all political actors.

In the case of the other two political parties in the governing coalition, we do not identify an increased interest in this issue. The SME RODINA movement, the second strongest government party with the election result of $8.24 \%$, does not profile itself in the conservative-liberal division, and considers such a division of parties to be overcome. Depending on this, the election program did not address the issue of financing churches and their overall position in society. According to the statement of the chairman Boris Kollár, legislative changes are already implemented within the framework of Act no. 370/2019 Coll. on financial support for the activities of churches and religious societies, for which all representatives of the SME RODINA parliamentary group voted in the 2016-2020 election period. ${ }^{17}$ The smallest member of the governing coalition is ZA L'UDÍ with a gain of $5.77 \%$ of the vote. Although the group profiled itself as a conservative entity, the election program did not contain specific mentions of the position of churches in society and the method of financing. According to their leader Veronika Remišová, churches are important actors in the democratization of society after 1989 and at present it is not appropriate to raise the sensitive issue of their financing.

\section{Opposition political parties}

In assessing the current opposition, its diversity needs to be emphasized. On the one hand, it is represented by SMER-SD as a left-wing political entity operating on the political scene since 1999, on the other hand, the L'SNS, which is considered to be a far-right political entity according to analysts. In this context, it is desirable to say that both these political entities have recently experienced the break-up of the party. SMER-SD has long avoided the issue of separation of state and church. We have been seeing this approach practically since the first parliamentary elections in 2002 , in which the party took part for the very first time. They rejected any indications of reforms on the grounds that Slovakia was not prepared for the conservative nature of society and its specific history. This issue was not

17 MOVEMENT WE ARE FAMILY, 2020. 
opened until the second government of Robert Fico through the Minister of Culture Marek Mad'arič. In the proposals of the Ministry, three alternatives were submitted for discussion. The first spoke about allocation tax models according to the model of Western European countries, the second about changes in state funding depending on the number of members of individual churches, and the third proposed to leave the matter in the status quo. We have assessed above why the second option finally won, albeit only in 2019. If we focus on the SMER-SD election program in the last parliamentary elections, this topic was not part of their 25-point document. According to the representatives of SMER-SD, the change of financing by the adoption of a modified model on the basis of Act no. 370/2019 Coll. on financial support for the activities of churches and religious societies was the optimal solution based on the specifics of Slovak society, thus the issue is already resolved and closed. The second parliamentary opposition body, the L'SNS, placed the Christian character of Slovakia at the forefront of the election program. Although the protection of these values is emphasized in several parts of the document, it does not deal specifically with the relationship between the state and the churches. ${ }^{18}$

\section{Conclusion}

Political parties are important actors in the process of changing the position of churches after 1989. The connection with political parties could be identified mainly in the cases of $\mathrm{KDH}$ and HZDS, which we demonstrated on specific examples. During the government of Mikulás Dzurinda, the basic framework of the Vatican Treaty was signed. It was reflected in the instability of the governing coalition. Ultimately, differing views of political parties led to early parliamentary elections in 2006 and creation of new government under Róbert Fico. In assessing the current development, we have clearly focused on the approaches of political parties to the issue of financial separation of state and churches according to the models of foreign countries. However, the official election programs in 2020 did not go into this topic in depth at all, for several reasons. In the first place, it was a relatively tricky topic for political parties, as a larger percentage of the population of Slovakia is in favour of conservative values. Fear of losing voters has become crucial. Neither political party of the current governing coalition dealt with the modification of the applied model or creating a completely new system. In the case of some political parties such as OL'ANO, we perceive party fragmentation very strongly, as there are no unified positions towards these issues. 


\section{References}

\section{Legal sources:}

Act no. 16/1990 Coll. on the abolition of state supervision over churches

Act no. 308/1991 Coll. on Freedom of Religion, the Status of Churches and Religious Societies

Act no. 229/1991 Coll. on the regulation of ownership

Act no. 308/1991 Coll. on Freedom of Religion, the Status of Churches and Religious

Act no. 648/2002 on the spiritual service of Catholic believers in the armed forces and in the armed corps

Act no. 394/2004 Coll. on Catholic education and the declaration of equality for church schools

Act no. 370/2019 Coll. on financial support for the activities of churches and religious societies

NATIONAL COUNCIL OF THE SLOVAK REPUBLIC, online: Details of Act no. 370/2019 Coll. on financial support for the activities of churches and religious societies <https:// www.nrsr.sk/web/Default.aspx?sid=zakony/zakon\&MasterlD=7450>

PEOPLE'S PARTY OUR SLOVAKIA 2020, online:

<http://www.naseslovensko.net/kategoria/nasenazory/krestanstvo-a-tradicie/>

JUST, Petr: Nad Tatrou sa blýska - strany, vlády a koalice na Slovensku v letech 2006 až 2016, Bratislava 2018, 163.

LETZ, Róbert: Slovenské dejiny VI., Bratislava 2021, 476.

MARUŠIAK, Juraj: Sviečková manifestácia v kontexte vzt́ahov medzi "krestáanským" a "občianským” disentom v rokoch 1988-1989, in: Sviečková manifestácia I., Bratislava 2015, 50-77.

MIKUŠ, Dalibor: Pohlady politických strán na verejnú správu, Trnava 2018, 118.

MOVEMENT WE ARE FAMILY, online: <https://hnutie-smerodina.sk/dokumenty/FinalProgram-SMERODINA-volebny-program.pdf> 
MULíK, Peter: Metódy a formy proticirkevnej politiky v komunistických štátoch strednej a juhovýchodnej Európy a ich zmeny v rokoch 1945-1989, in: Prenasledovanie cirkví $v$ komunistických štátoch strednej a východnej Európy, Bratislava 2009, 234-273.

PEŠEK, Jan: Štátnopolitické orgány dozoru nad cirkvami na Slovensku v rokoch 1948-1989, in: Prenasledovanie cirkví v komunistických štátoch strednej a východnej Európy, Bratislava 2009, 510-527.

PŘIBYL, Stanislav: Problémy spjaté s utvářením nového modelu financování cirkví v České republice, in: Financovanie cirkví a náboženských spoločností v modernom demokratickom štáte, Bratislava 2019, 121-131.

SCHANDA, Balász: Financovanie cirkví a náboženských spoločností v Mad'arsku, in: Financovanie cirkví a náboženských spoločností v 21. storočí, Bratislava 2010, 81-91.

ŠABO, Martin: Systém vztáahov medzi štátom a cirkvami v Československu pred prijatím zákona č. 218/1949 Zb. o hospodárskom zabezpečení cirkví a náboženských spoločností, in: Prenasledovanie cirkví v komunistických štátoch strednej a východnej Európy, Bratislava 2009, 192-205.

ŠABO, Martin: Moderné spôsoby priamej podpory štátu cirkvám a náboženským spoločnostiam vo svete, in: Financovanie cirkví a náboženských spoločností v modernom demokratickom štáte, Bratislava 2019, 97-110.

TiŽIK, Miroslav: Náboženstvo vo verejnom živote na Slovensku, Bratislava 2012, 426.

WADOWSKI, Dariusz: Religion and Religiosity in Contemporary Poland, in: Central European Journal of Contemporary Religion, 3, 2019, 1, 35-63.

\section{Author}

PhDr. Dalibor Mikuš, PhD.

University of Ss. Cyril and Methodius in Trnava,

Faculty of Social Sciences

Department of Public Administration

Nám. J. Herdu 2, Trnava, Slovakia

dalibor.mikus@ucm.sk 